\title{
Risiko Terjadinya Limfedema pada Pasien Kanker Payudara yang Mengalami Infeksi Setelah Menjalani Operasi Terkait Usia di Rumah Sakit Dharmais
}

\author{
Dadan Prayogo \\ Mahasiswa Program Studi Magister Fisiologi Olahraga, Universitas Udayana \\ e-mail: dadanprayogo@yahoo.co.id
}

\begin{abstract}
Lymphedema in breast cancer is a disruption of the lymphatic system, resulting in the accumulation of fluid rich in protein in the interstitial space which causes swelling of the arms, shoulders, neck, or thoracic region. The purpose of this study was to determine the risk of lymphedema in breast cancer patients who experienced infection after undergoing agerelated surgery. This research method uses a quantitative research design, with a multicentre approach, and uses a casecontrol design with a total of 110 subjects. Interviews and measurements were carried out using a questionnaire. The results of the study showed that breast cancer patients who experienced infection after surgery were 3.5 times more likely to develop lymphedema than those who did not experience infection after surgery. Patients aged 50 years with lymphedema were 1.4 times more likely to develop lymphedema than those $<50$ years. In conclusion, patients who experienced infection after surgery with an age of $\geq 50$ years to the incidence of lymphedema were found to be $75.0 \%$ with an aOR of 1, this means that cOR aOR, so there was an indication as a confounding factor, but statistically there was no significant difference with $p$ value $>0.05$.
\end{abstract}

Keywords: Breast Cancer, Infection After Surgery, Lymphedema, Without Lymphedema.

\begin{abstract}
Abstrak
Limfedema pada kanker payudara adalah terganggunya sistem limfatik sehingga menimbulkan akumulasi cairan yang kaya dengan protein di ruang interstisial yang menyebebkan terjadinya pembengkakan lengan, bahu, leher, atau daerah thorak. Tujuan penelitian ini untuk mengetahui risiko terjadinya limfedema pada pasien kanker payudara yang mengalami infeksi setelah menjalani operasi terkait usia. Metode penelitian ini menggunakan rancangan penelitian kuantitatif, dengan pendekatan multicente, dan menggunakan desain case-control dengan total 110 subjek. Wawancara dan pengukuran telah dilakukan menggunakan kuesioner. Hasil dari penelitian menunjukkan bahwa pasien kanker payudara yang mengalami infeksi setelah operasi 3,5 kali lebih berisiko terjadi limfedema dibandingkan yang tidak mengalami infeksi setelah operasi. Pasien yang berusia $\geq 50$ tahun yang mengalami limfedema 1,4 kali lebih berisiko terjadi limfedema dibanding $<50$ tahun. Kesimpulan, pasien yang mengalami infeksi setelah operasi dengan usia $\geq 50$ tahun terhadap kejadian limfedema ditemukan $75,0 \%$ dengan aOR 1 , ini berarti cOR $\neq$ aOR, sehingga ada indikasi sebagai faktor pengganggu, namun secara statistik tidak ada perbedaan yang bermakna dengan $p$ value $>0,05$.
\end{abstract}

Kata Kunci: Kanker Payudara, Infeksi Setelah Operasi, Limfedema, Tanpa Limfedema.

\section{Pendahuluan}

Data perkiraan globocan (global burden of cancer), sekitar 14,1 juta kasus kanker baru dan 8,2 juta kematian terjadi di tahun 2012 di seluruh dunia. Selama bertahun-tahun, beban tersebut telah bergeser ke negara-negara kurang berkembang, yang saat ini mencakup sekitar $57 \%$ kasus, dan $65 \%$ kematian akibat kanker di seluruh dunia. Kanker payudara adalah kanker yang paling sering didiagnosis dan penyebab utama kematian akibat kanker di antara wanita seluruh dunia, dengan kisaran 1,7 juta kasus dan 522.000 kematian pada tahun 2012. Kanker payudara menyumbang $25 \%$ dari semua kasus kanker dan $15 \%$ dari semua kematian akibat kanker di kalangan wanita. Separuh dari kasus baru terjadi di negara maju, dan 38\% kematian Torre et al., (2015).

Hampir 116.000 kematian (22\%) di seluruh wilayah Asia Pasifik dengan tingkat 8 per 100.000 jiwa. China menyumbang $41 \%$ kematian akibat kanker payudara pada kalangan wanita, diikuti oleh Indonesia (17\%) dan Jepang (12\%). Tingkat kematian setiap subregional bervariasi dari 6 per 100.000 jiwa di Asia Timur, 14 per 100.000 jiwa di Asia Tenggara dan 16 per 100.000 jiwa di Oseania. Negara Fiji dilaporkan memiliki tingkat kematian tertinggi untuk kanker payudara wanita di Asia Pasifik (28 per 100.000 
Jurnal Keperawatan Suaka Insan (JKSI) Vol. 6, No. 1, Juni 2021

jiwa), diikuti oleh Kepulauan Solomon (24 per 100.000 jiwa) dan Kaledonia Baru (23 per 100.000 jiwa) Youlden et al., (2014).

Indonesia dalam sepuluh tahun terakhir ini, kanker payudara masuk enam besar penyebab kematian di Indonesia. Pencatatan pemeriksaan jaringan, kanker payudara mempunyai angka kejadian relatif $11,5 \%$. Diperkirakan di Indonesia mempunyai kejadian minimal 20.000 kasus pertahun. Prevalensi kejadian tumor/kanker di Indonesia sendiri, menurut Riset Kesehatan Dasar (RisKesDas) tahun 2007 adalah sebesar 4,3 per 1.000 penduduk. Sementara berdasarkan data Sistem Informasi Rumah Sakit (SIRS) tahun 2007, kejadian kanker payudara sebanyak 8.227 kasus atau 16,85\%. Sebagai tambahan, penyakit kanker payudara merupakan penyakit kanker dengan prevalensi tertinggi kedua di Indonesia pada tahun 2013 RisKesDas, (2013). Masih pemaparan oleh RisKesDas tahun 2013, daerah DKI Jakarta memiliki jumlah estimasi yang absolut sekitar 3.946 penderita atau sekitar $0.8 \%$, prevalensi ini diambil beradasarkan dari status setelah didiagnosa oleh dokter. Sebagai salah satu institusi rujukan khsusus kanker payudara, Rumah Sakit Dharmais mencatat kanker terbanyak selama 4 tahun berturutturut adalah kanker payudara, serviks, paru, ovarium, rektum, tiroid, usus besar, hepatoma, dan nasofaring (Instalasi Deteksi Dini dan Promosi Kesehatan Rumah Sakit Kanker Dharmais, 2010-2013).

Penderita kanker payudara kemudian menjalani perawatan yang paling sering mencakup pembedahan, radioterapi, kemoterapi, terapi hormonal, dan terapi yang ditargetkan, atau dengan kombinasi perawatan lain De Rinaldis, Tutt, \& Dontu, (2011). Namun, beberapa perawatan tersebut dan faktor-faktor lainnya dapat menimbulkan komplikasi limfedema ekstremitas atas dengan kejadian yang dilaporkan berkisar $17 \%$ dengan menggunakan data yang diambil dari 72 penelitian terhadap 29.612 wanita dengan kanker payudara.

Limfedema pada kanker payudara adalah keadaan terganggunya sistem limfatik yang menimbulkan akumulasi cairan kaya dengan protein di ruang interstisial dan pada akhirnya menimbulkan pembengkakan lengan, bahu, leher, atau daerah thorak yang terjadi lebih dari 3 bulan (Fu, Ridner, \& Armer, (2009); Gurdal et. al, (2012); warren et al, (2013)). Kondisi ini menimbulkan masalah berupa edema kronis, rasa ketidaknyamanan, kehilangan fungsi tubuh, kelainan bentuk tubuh dan kelelahan Damstra \& Partsch, (2013); Huang et al., (2013). Perubahan psikologis juga diamati dan berdampak negatif pada citra tubuh dan harga diri Neil-Sztramko et al., (2014).
Penelitian yang dilakukan oleh Ugur et al., (2013) menunjukkan usia rata-rata dari 455 pasien adalah 50,6 tahun. Limfedema ditemukan pada 124 (27\%) pasien. Sebagian besar pasien dengan riwayat luka infeksi setelah pembedahan (52\%) Odd's ratio: 3,11 (CI: 95\% 1,41; 6,82) $(\mathrm{p}=0,003)$. Penelitian meta analisis oleh Zhu et al., (2014) menunjukkan ada dua puluh lima penelitian yang teridentifikasi, terdiri dari 12.104 pasien. Dalam penelitian ini, faktor risiko penting BCRL komplikasi pasca operasi dan gabungan OR dan 95\% CI (OR = 2,64, 95\% CI 1,10 sampai 6,30). $\mathrm{p}=0,029<0,05$ dianggap signifikan secara statistik pasca operasi komplikasi terutama mengacu pada infeksi dalam penelitian ini.

Penelitian Mak et al., (2009) menemukan bahwa infeksi/pembengkakan lengan atau dada adalah mayor faktor risiko untuk pengembangan atau terjadinya lymphedema. Dalam penelitian menunjukkan bahwa risiko berkembang lymphedema pada pasien dengan riwayat infeksi luka 3,11 kali lebih banyak daripada mereka yang tidak mengalami infeksi/pembengkakan dini $(p=0,003)$, dan pada pasien yang memiliki riwayat limfangitis, risikonya 3,83 kali lebih tinggi dari yang tidak $(p=0,002)$. Infeksi dapat menjadi faktor awal dan lebih mungkin untuk memperburuk limfedema yang ada, kedua temuan ini signifikan secara statistik. Gil-Londoñoa et. al., (2016) menunjukkan bahwa adanya seroma hematom pasca operasi dan penggunaan alat drainase jangka panjang adalah faktor risiko independen untuk SSI (surgical site infection) dalam operasi kanker payudara onkologis. Sebanyak 308 prosedur bedah payudara onkologi yang dilakukan secara berturutturut, 161 (52,3\%) adalah kuadranektomi dan 147 $(47,7 \%)$ adalah setelah menjalani pembedahan, dengan kejadian SSI sebesar 16,2\% (50 kasus). Faktor risiko yang terkait adalah seroma-hematoma, yang terjadi pada $79(25,6 \%)$ kasus, waktu rata-rata untuk pengembangan atau pembengkakan SSI adalah 16 hari.

Warren MD et al., (2013) menunjukkan bahwa faktor lain yang signifikan untuk meningkatkan risiko lymphedema pada analisis multivariat mencakup pembengkakan pasca operasi awal (HRZ 10.3, P $<.0001)$. Sebuah studi sebelumnya oleh Mahamaneerat dkk mengevaluasi kegiatan pasca operasi angkat kaki, dan menemukan faktor risiko peningkatan lymphedema sebanyak 5\% volume lengan, 1 bulan setelah operasi terkait dengan peningkatan risiko lymphedema 1,4 kali lipat. Menariknya, dalam penelitian ini, pembengkakan post operatif dini diberikan paling tinggi risiko lymphedema untuk semua variabel yang dianalisis. Infeksi/edema dini adalah faktor risiko signifikan limfedema dalam analisis univariat $(\mathrm{p}<0,05)$. Semua 
Jurnal Keperawatan Suaka Insan (JKSI) Vol. 6, No. 1, Juni 2021

faktor dengan nilai $p<0,05$ termasuk dalam analisis multivariate (Wang (2016)).

Banyak penelitian yang dilakukan untuk mengetahui perawatan yang berkontribusi terhadap terjadinya limfedema. Termasuk penelitian yang dilakukan oleh Togawa et al, (2014), Pada kelompok usia tertua (60 - 64 tahun) memiliki risiko yang lebih rendah dari limfedema dari usia termuda kelompok (35-44 tahun) pada akhir onset. Usia lebih tua dikaitkan dengan penurunan risiko akhir onset limfedema $(P=0.002)$, tetapi tidak dengan awal limfedema $(\mathrm{P}=0,91)$. Risiko akhir onset limfedema mengalami penurunan sebesar $5 \%$ per tahun bersama dengan peningkatan usia (HR $=0,95,95 \%$ CI: 0,92-0,98). Perbedaan yang signifikan di usia pada awal onset dan akhir onset limfedema saat usia diperlakukan sebagai kontinyu ( $\mathrm{P}$ $=0,02$ ). Sedangkan beberapa penelitian lain berbeda dengan penelitian Togawa, et al, 2014 terkait usia yang dilakukan oleh SS Mak et al, (2009), studi ini menemukan usia yang lebih tua adalah faktor risiko yang terkait dengan inisiasi limfadema. Usia yang lebih tua pada juga terkait dengan tingkat keparahan limfedema. Sedangkan Coriddi et al, (2015) dalam analisis univariat menyebutkan bahwa faktor yang terkait dengan limfadema secara signifikan lebih tinggi termasuk usia $\geq 50$ tahun ( $p=0.018$ ), usia lebih dari 50 tahun dapat meningkatkan risiko kejadian limfedema menjadi 3,3 kali, tampaknya pada orang tua lebih cenderung kurang melakukan aktivitas fisik sehingga terjadi kelemahan pemompaan pada otot untuk sirkulasi balik cairan yang menyebabkan limfedema Shahpar et al, (2013). Penelitian terbaru yang dilakukan oleh Yehia Safwat et. al (2017) menunjukkan faktor yang terkait dengan peningkatan kejadian limfedema secara signifikan termasuk usia lebih tua $(p=0,018)$. Sedangkan, analisis multivariabel menemukan usia lebih tua dikaitkan dengan kejadian limfedema yang lebih tinggi, analisis univariat menunjukkan perbedaan yang signifikan antara kelompok pasien dengan lymphedema dan orang-orang tanpa lymphedema berkenaan dengan usia yang lebih tua $(0,016)$.

\section{Metode}

Penelitian ini menggunakan rancangan penelitian kuantitatif, karena hasil pengamatan dikonversikan kedalam angka-angka sehingga dapat digunakan teknik statistik untuk menganalisis hasilnya, dengan menggunakan pendekatan multicenter. Penelitian ini dilakukan 3 bulan, dimulai bulan Desember 2015 sampai dengan bulan Februari 2016. Penelitian ini bertujuan untuk mendeskripsikan risiko terjadinya limfedema pada pasien kanker payudara yang mengalami infeksi setelah menjalani operasi terkait usia di rumah sakit Dharmais Jakarta.
Target populasi dalam penelitian ini adalah wanita yang memiliki diagnosis kanker payudara yang disertai atau tanpa disertai limfedema di rumah sakit Kanker Dharmais Jakarta dan rumah sakit Ulin Banjarmasin.

Sampel dalam penelitian ini adalah populasi yang memenuhi standar kriteria inklusi. Jumlah sampel minimum yang ditargetkan dalam penelitian ini dihitung dengan menggunakan rumus case-control study, yaitu $\mathrm{N}=21 \mathrm{p} \mathrm{q} /\left(\mathrm{p}_{1}-\mathrm{p}_{0}\right)^{2}$. Hasil perhitungan sampel dengan menggunakan rumus kasus diperoleh sampel minimal di Rumah Sakit Kanker Dharmais Jakarta sebanyak 48 subyek untuk kelompok kasus dan di Rumah Sakit Ulin Banjarmasin 48 subyek untuk kelompok kontrol. Sampel minimal untuk kedua kelompok adalah 96 subyek, dan dibulatkan menjadi 110 subyek untuk mencegah terjadinya drop out observasi klinis lanjutan sampai pada akhir penelitian.

Sebelum dilakukan analisa data univariat dan bivariate akan dilakukan pengolahan data untuk variabel infeksi setelah menjalani operasi, kanker payudara dengan atau tanpa limfedema, karakteristik demografi faktor usia. Analisa univariat digunakan untuk melihat variabel yang akan diamati dan apakah ada perbedaan yang bermakna diantara variabel tersebut. Analisa univariat terhadap infeksi setelah menjalani operasi, dan variabel confounding usia.

Analisa univariat digunakan untuk melihat perbedaan setiap variabel yang diteliti antara limfedema dan tanpa limfedema dan distribusi masing-masing variabel secara deskriptif. Untuk variabel limfedema dan tanpa limfedema dibuat dalam bentuk tabel distribusi frekuensi dan persentase terkait infeksi setelah menjalani operasi dan usia. Untuk variabel berskala interval seperti usia, akan diuji untuk melihat perbedaan rata-rata usia pada kasus limfedema dan tanpa limfedema menggunakan $T$ Test jika berdistribusi normal dan Mann Whitney jika berdistribusi tidak normal. Sedangkan, untuk variabel infeksi setelah menjalani operasi akan diuji menggunakan Chi Square.

Analisa bivariat bertujuan untuk mengetahui besaran risiko terjadinya limfedema pada pasien kanker payudara yang menerima tindakan radioterapi. Analisa ini juga bertujuan untuk melihat besaran risiko terjadinya limfedema menurut faktor usia yang skalanya telah dikategorikan. Variabel usia juga diduga merupakan faktor pengganggu. Uji analisis yang akan digunakan pada penelitian ini adalah Crude Odds Ratio (cOR) yang bertujuan untuk mengetahui efek Odds Ratio (OR) dari masingmasing variabel independen terhadap variabel dependen dan Adjusted Odds Ratio (aOR) yang 
Jurnal Keperawatan Suaka Insan (JKSI) Vol. 6, No. 1, Juni 2021

bertujuan untuk mengetahui efek Odds Ratio (OR) dari variabel independen dan variabel pengganggu terhadap variabel dependen. Jika nilai $p$ value pada uji Odds Ratio < 0,05, maka pada interval kepercayaan $95 \%$, Odds Ratio dinyatakan signifikan atau bermakna.

\section{Hasil Penelitian}

\section{Analisa Univariat}

Deskripsi subjek penelitian dilakukan dengan analisis univariat untuk melihat distribusi karakteristik subjek penelitian, yaitu variabel usia berdasarkan variabel infeksi setelah operasi dan limfedema lengan.

Tabel 1. Distribusi frekuensi dan persentase kejadian limfedema dan tanpa limfedema berdasarkan infeksi setelah operasi

\begin{tabular}{ccccc}
\hline $\begin{array}{c}\text { Infeksi } \\
\text { setelah } \\
\text { operasi }\end{array}$ & $\begin{array}{c}\text { Limfedema } \\
\mathrm{n}(\%)\end{array}$ & $\begin{array}{c}\text { Tanpa } \\
\text { Limfedem } \\
\mathrm{a} \\
\mathrm{n}(\%)\end{array}$ & $\begin{array}{c}\text { Total } \\
(\%)\end{array}$ & $p$ \\
\hline Ya & 9 & 3 & $12(100)$ & 0,0 \\
& $(75.0)$ & $(25.0)$ & 43 & $81^{*}$ \\
Tidak & 20 & 23 & $(100)$ & $*$ \\
& $(46.5)$ & $(53.5)$ & 55 & 100 \\
Total & 29 & $26(47,3)$ & $(100)$ & $\%$ \\
\hline \multicolumn{7}{r}{ Keterangan: $(*)$ bermakna dan $(* *)$ tidak bermakna }
\end{tabular}

Distribusi frekuensi dan persentase yang mengalami infeksi setelah operasi memiliki persentase lebih tinggi (75.0\% dari 12 subjek penelitian) dibandingkan yang tidak mengalami infeksi setelah operasi $(46,5 \%$ dari 43 subjek penelitian), tapi diantara kedua kelompok tersebut ditemukan tidak ada perbedaan yang bermakna dengan hasil $p$ value 0,081 .
Tabel 2. Nilai Rata-Rata, Mean \pm SD, Minimal, Maksimal, Interval Kepercayaan 95\% Kejadian limfedema dan tanpa limfedema berdasarkan usia

\begin{tabular}{|c|c|c|c|c|c|}
\hline Variabel (n) & $\begin{array}{l}\overline{\mathrm{x}} \pm \\
\mathrm{SD}\end{array}$ & $\begin{array}{c}\mathrm{Mi} \\
\mathrm{n}\end{array}$ & $\begin{array}{c}\mathrm{Ma} \\
\mathrm{k}\end{array}$ & $\begin{array}{c}\text { CI } \\
(95 \% \\
\quad) \\
\end{array}$ & $P$ \\
\hline $\begin{array}{l}\text { Limfede } \\
\text { ma (29) }\end{array}$ & $\begin{array}{c}53,0 \\
7 \pm \\
9,94 \\
6\end{array}$ & 38 & 82 & $\begin{array}{c}49,2 \\
9- \\
56,8 \\
5\end{array}$ & $010 *$ \\
\hline $\begin{array}{l}\text { Tanpa } \\
\text { Limfede } \\
\text { ma (26) }\end{array}$ & $\begin{array}{c}49,3 \\
1 \pm \\
6,55 \\
3\end{array}$ & 36 & 64 & $\begin{array}{c}46,6 \\
6- \\
51,9 \\
5\end{array}$ & $*$ \\
\hline
\end{tabular}

Usia rata-rata pasien yang mengalami limfedema adalah 53,07 tahun dengan 95\% kepercayaan 49,2956,85 tahun. Sedangkan tanpa limfedema 49,31 tahun dengan 95\% kepercayaan 46,66-51,95 tahun. Hasil uji statistic menunjukkan tidak ada perbedaan usia rata-rata yang bermakna pada kasus limfedema dan tanpa limfedema $(p=0,10)$.

\section{Analisa Bivariat}

Tabel 3 Distribusi frekuensi, cOR, CI 95\%, serta berdasarkan variabel infeksi dan usia

\begin{tabular}{cccccc}
\hline $\begin{array}{c}\text { Infeksi } \\
\text { setelah } \\
\text { operasi }\end{array}$ & $\begin{array}{c}\text { Limfede } \\
\text { ma }\end{array}$ & $\begin{array}{c}\text { Tanpa } \\
\text { Limfede } \\
\text { ma }\end{array}$ & $\begin{array}{c}\mathrm{cO} \\
\mathrm{n}(\%)\end{array}$ & $\begin{array}{c}\mathrm{CI} \\
95\end{array}$ & $p$ \\
\hline Ya & $9(75.0)$ & $3(25.0)$ & & 0,8 & \\
Tidak & $20(46.5)$ & 23 & 3,5 & - & $0,09 *$ \\
& & $(53.5)$ & & 5 & $*$ \\
Usia & & & & 0,5 & $0,50^{*}$ \\
$\geq \quad 50$ & 16 & $12(42,9)$ & 1,4 & - & $*$ \\
$\begin{array}{l}\text { Tahun } \\
<\quad 50\end{array}$ & $(57,1)$ & & & 4,2 & \\
Tahun & 13 & $14(51,9)$ & & & \\
\hline \multicolumn{5}{l}{ Keterangan: $(*)$ bermakna dan $(* *)$ tidak bermakna }
\end{tabular}

Infeksi setelah operasi memiliki peran 3,5 kali untuk meningkatkan kejadian limfedema dibanding yang tidak mengalami infeksi setelah operasi, walaupun secara statistik tidak ditemukan perbedaan yang bermakna $(p=0,09)$. Usia $\geq 50$ tahun dan usia $<50$ tahun tidak memiliki perbedaan risiko yang bermakna terhadap terjadinya limfedema $(p=0,50)$. Namun, usia $\geq 50$ tahun ditemukan memiliki peran 1,4 kali terhadap terjadinya limfedema dibanding usia $<50$ tahun. 
Jurnal Keperawatan Suaka Insan (JKSI) Vol. 6, No. 1, Juni 2021

Tabel 4. Distribusi Frekuensi, persentase, aOR, Dan CI 95\% Berdasarkan Variabel infeksi setelah operasi Terkait Faktor Pengganggu Usia

\begin{tabular}{lllll}
\hline $\begin{array}{l}\text { Infeksi } \\
\text { setelah } \\
\text { operasi }\end{array}$ & Limfedema & $\begin{array}{c}\text { Tanpa } \\
\text { Limfedema }\end{array}$ & aOR & $\begin{array}{c}\text { CI } \\
95 \%\end{array}$ \\
\hline $\begin{array}{l}\geq 50 \\
\text { Tahun } \\
<50\end{array}$ & $3(75,0 \%)$ & $1(25,0 \%)$ & 1 & $0,1-$ \\
$\begin{array}{l}\text { Tahun } \\
\text { Tahun }\end{array}$ & $6(75,0 \%)$ & $2(25,0 \%)$ & 1 & 16,0 \\
\hline
\end{tabular}

Usia $\geq 50$ tahun memiliki aOR 1 yang berarti cOR tidak sama dengan aOR. Jadi, usia $\geq 50$ tahun menjadi indikasi yang dapat mengganggu besaran kejadian limfedema pada pasien yang mengalami infeksi setelah operasi, tapi secara statistik tidak ditemukan adanya perbedaan yang bermakna ( $p$ value $=0,50$ ).

\section{PEMBAHASAN}

\section{Infeksi Setelah Menjalani Operasi}

Hasil deskriptif subjek penelitian yang dilakukan di rumah sakit Dharmais Jakarta, dari 55 responden didapatkan pasien kanker payudara yang mengalami infeksi setelah operasi, 12 orang dengan persentase $21,8 \%$ yang tidak mengalami infeksi setelah operasi 43 orang dengan persentase $78,2 \%$.

Pasien kanker payudara yang mengalami infeksi setelah operasi terjadi limfedema sebesar 75,0\% dan yang tidak mengalami infeksi setelah operasi terjadi limfedema 46,5\%, OR = 3,5 CI 95\% $(0,8-14,5) p$ value 0,09 . Pasien kanker payudara yang mengalami infeksi setelah operasi 3,5 kali lebih berisiko terjadi limfedema dibandingkan yang tidak mengalami infeksi setelah operasi, tetapi nilai $p>0,05$ tidak signifikan.

Penelitian ini tidak sejalan dengan penelitian yang pernah dilakukan SS Mak et al, (2009) yang menemukan bahwa infeksi lengan atau dada adalah mayor faktor risiko untuk pengembangan atau terjadinya lymphedema. Dalam penelitian menunjukkan bahwa risiko berkembang limfedema pada pasien dengan riwayat infeksi luka 3,11 kali lebih banyak daripada mereka yang tidak mengalami infeksi dini $(p=0,003)$, dan pada pasien yang memiliki riwayat limfangitis, risikonya 3,83 kali lebih tinggi dari yang tidak $(p=0,002)$. Infeksi dapat menjadi faktor awal dan lebih mungkin untuk memperburuk limfedema yang ada, kedua temuan ini signifikan secara statistik. Gil-Londoñoa et. al (2016), studi ini menunjukkan bahwa adanya seroma hematom pasca operasi dan penggunaan alat drainase jangka panjang adalah faktor risiko independen untuk
SSI (surgical site infection) dalam operasi kanker payudara onkologis. Sebanyak 308 prosedur bedah payudara onkologi berturut-turut yang dilakukan, 161 $(52,3 \%)$ adalah kuadranektomi dan $147(47,7 \%)$ adalah setelah menjalani pembedahan dengan kejadian SSI sebesar 16,2\% (50 kasus). Faktor risiko yang terkait adalah seroma-hematoma, yang terjadi pada $79(25,6 \%)$ kasus, waktu rata-rata untuk pengembangan atau pembengkakan SSI adalah 16 hari. Warren MD et al (2013) menunjukkan bahwa faktor lain yang signifikan untuk meningkatkan risiko limfedema pada analisis multivariat mencakup pembengkakan pasca operasi awal (HRZ 10.3, P $<.0001)$. Sebuah studi sebelumnya oleh Mahamaneerat dkk menunjukkab bahwa evaluasi hasil pasca operasi angkat kaki, dengan faktor risiko limfedema, ditemukan peningkatan $5 \%$ volume lengan 1 bulan setelah operasi. Hal ini menunjukkan peningkatan risiko lymphedema 1,4 kali lipat. Menariknya, dalam penelitian ini, pembengkakan post-operatif dini diberikan paling tinggi pada risiko lymphedema untuk semua variabel yang dianalisis. Infeksi/edema dini adalah faktor risiko signifikan limfedema dalam analisis univariat $(p<0,05)$ Semua faktor dengan nilai $p$ kurang dari 0,05 termasuk dalam analisis multivariate (Wang 2016).

\section{Usia}

Hasil deskriptif subjek penelitian yang dilakukan di rumah sakit Kanker Dharmais Jakarta tahun 2015, dari 55 responden didapatkan pasien kanker payudara yang berusia $\geq 50$ tahun sebesar 28 orang $50,9 \%$ dan yang berusia $<50$ tahun sebanyak 27 orang dengan presentase $49,1 \%$.

Pasien kanker payudara yang mengalami limfedema rata-rata usia 53,07 tahun, berusia $\geq 50$ tahun yang mengalami limfedema sebesar $57,1 \%$ dan yang berusia < 50 tahun yang mengalami limfedema sebesar $48,1 \%$, OR = 1,4 CI 95\% (0,5 - 4,2) p-value $=0,50$. Pasien kanker payudara yang berusia $\geq 50$ tahun 1,4 kali lebih berisiko terjadi limfedema dibanding $<50$ tahun, namun nilai $\mathrm{p}>0,05$ yang berarti tidak signifikan.

Pasien kanker payudara yang mengalami infeksi setelah operasi yang memiliki usia $\geq 50$ tahun terhadap kejadian limfedema ditemukan 75,0\% dengan aOR 1 . Ini berarti cOR $\neq \mathrm{aOR}$, sehingga ada indikasi sebagai faktor pengganggu, namun secara statistik tidak ada perbedaan yang bermakna dengan $p$ value $>0,05$.

Penelitian ini tidak sejalan dengan penelitian yang pernah dilakukan SS Mak et al (2009), studi ini menemukan usia yang lebih tua adalah faktor risiko yang terkait dengan inisiasi limfadenema. Usia yang lebih tua dengan $\mathrm{OR}=1,04, \mathrm{CI}=(1,01-1,07)$ dengan 
Jurnal Keperawatan Suaka Insan (JKSI) Vol. 6, No. 1, Juni 2021

P-value 0.03 mempengaruhi tingkat keparahan limfedema. Shahpar, et al (2013) menunjukkan bahwa limfedema dikaitkan dengan usia yang lebih muda di diagnosis (OR per tahun dari usia $=0,96, \mathrm{CI}$ $=0,93-0,99)$, usia lebih dari 50 tahun dapat meningkatkan risiko kejadian limfedema menjadi 3,3 kali. Hal ini menunjukkan bahwa tampaknya pada usia yang lebih tua, individu lebih cenderung kurang melakukan aktivitas fisik, sehingga terjadi kelemahan pemompaan pada otot untuk sirkulasi balik cairan yang menyebabkan limfedema. Penelitian terbaru yang dilakukan oleh Yehia Safwat et. al (2017) menunjukkan bahwa faktor yang terkait dengan peningkatan kejadian limfedema secara signifikan termasuk usia lebih tua $(\mathrm{p}=0,018)$. Sedangkan, analisis multivariable menemukan bahwa usia lebih tua dikaitkan dengan kejadian limfedema yang lebih tinggi., analisis univariat menunjukkan perbedaan yang signifikan antara kelompok pasien dengan lymphedema dan orang-orang tanpa lymphedema berkenaan dengan usia yang lebih tua $(0,016)$, sementara itu analisis regresi logistik ganda hanya menunjukkan usia tua $(0,005)$.

Alasan kenapa penelitian ini tidak signifikan yaitu dapat dilihat dari beberapa literatur yang mengatakan bahwa penyembuhan luka yang buruk atau perawatan yang tidak tepat akan menimbulkan kerusakan limfatik dan menghambat rekonstruksi limfatik dan pembentukan sirkulasi kolateral. Hal ini dapat memperparah atau menyebabkan lymphedema ekstremitas atas (Zhu et al., 2014). Pasca operasi angkat kaki sebagai faktor risiko lymphedema dan ditemukan peningkatan 5\% volume lengan, 1 bulan setelah operasi terkait dengan peningkatan risiko lymphedema 1,4 kali lipat (Warren Laura E.G et. al 2014). Gil-Londoñoa et. al (2016), Studi ini menunjukkan bahwa adanya seroma hematom setelah operasi dan penggunaan alat drainase jangka panjang adalah faktor risiko independen untuk SSI (surgical site infection) dalam operasi kanker payudara. Pada orang tua lebih cenderung kurang melakukan aktivitas fisik sehingga terjadi kelemahan pemompaan pada otot untuk sirkulasi balik cairan yang menyebabkan limfedema. (Shahpar, et al, 2013).

Peneliti menyimpulkan dari literatur diatas bahwa untuk perawatan di rumah sakit Kanker Dharmais Jakarta berkaitan dengan dengan perawatan luka setelah menjalani operasi pasien mendapatkan perawatan yang intensif, sehingga tidak menimbulkan komplikasi atau infeksi setelah menjalani operasi. Data sampel yang sedikit dan waktu atau lamanya penelitian juga mempengaruhi hasil yang diperoleh, dalam penelitian ini sampel yang digunakan hanya 12 orang dengan waktu penelitian tiga bulan.

\section{Kesimpulan}

Tujuan khusus persentase pasien kanker payudara yang mengalami infeksi setelah operasi 21,8\%, sedangkan pasien kanker payudara yang tidak mengalami infeksi setelah operasi sebesar 78,2\%. Pasien yang mengalami infeksi setelah operasi terjadi limfedema sebesar $75,0 \%$.

Terkait dengan variabel faktor pengganggu, rata-rata pasien kanker payudara yang mengalami limfedema berusia 53,07 tahun, dibandingkan dengan yang tidak limfedema dengan rata-rata 49,31 tahun. Namun, diantara kedua kelompok tersebut tidak ditemukan perbedaan yang bermakna. Pada pasien yang mengalami infeksi setelah operasi, terkait dengan usia $\geq 50$ tahun terjadinya limfedema ditemukan dengan persentase $75,0 \%$. Kedua kelompok usia tersebut (usia $\geq 50$ tahun dan usia $<50$ tahun) tidak mempengaruhi besaran kejadian limfedema pada pasien yang mengalami infeksi setelah operasi.

\section{Acknowledgement}

Terima kasih kepada Rumah Sakit Kanker Dharmais Jakarta dan Rumah Sakit Umum Daerah Ulin Banjarmasin yang sudah mengijinkan pelaksanaan penelitian ini.

\section{Referensi}

Coriddi, M., Khansa, I., Stephens, J., Miller, M., Boehmler, J., \& Tiwari, P. (2015). Analysis of factors contributing to severity of breast cancer-related lymphedema. Annals of Plastic Surgery,74(1),22-5.

https://doi.org/10.1097/SAP.0b013e31828d7 $\underline{285}$

Damstra, R. J., \& Partsch, H. (2013). Prospective, randomized, controlled trial comparing the effectiveness of adjustable compression Velcro wraps versus inelastic multicomponent compression bandages in the initial treatment of leg lymphedema. Journal of Vascular Surgery: Venous and Lymphatic Disorders, 1(1),13-19. https://doi.org/10.1016/j.jvsv.2012.05.001

De Rinaldis, E., Tutt, A., \& Dontu, G. (2011). Breast Cancer. Breast Pathology, 352-359. https://doi.org/10.1016/B978-1-4377-1757$\underline{0.00028-7}$

Fu, B. R. R. Rider, S. H., Armer, J, (2009). Postbreaset cancer 34, 109(8)

Gil-Londoria Joana-Cristina et. al (2016). Surgical site infection after breast cancer surgery at 30 
Jurnal Keperawatan Suaka Insan (JKSI) Vol. 6, No. 1, Juni 2021

day andassociated factor. Published by Elsever Espana, S. L. U. This in an open access article under the CC BY-NC-ND license http://creativecommons. org/licenses/by-nc$\mathrm{nd} / 4.0 /$

Gurdal, S. O., Kostanoglu, A., Cavdar, I., Ozbas, A., Cabioglu, N., Ozcinar, B., Ozmen, V. (2012). Comparison of intermittent pneumatic compression with manual lymphatic drainage for treatment of breast cancer-related lymphedema. Lymphatic Research and Biology, 10(3), 129-135. https://doi.org/10.1089//rb.2012.0002

Huang, T.-W., Tseng, S.-H., Lin, C.-C., Bai, C.-H., Chen, C.-S., Hung, C.-S., Tam, K.-W. (2013). Effects of manual lymphatic drainage on breast cancer-related lymphedema: a systematic review and meta-analysis of randomized controlled trials. World Journal of Surgical Oncology, 11(1), 15. https://doi.org/10.1186/1477-7819-11-15

Instalasi deteksi dini dan promosi kesehatan. rumah sakit Kanker Dharmais. (2013).

Neil-Sztramko, S. E., Kirkham, A. A., Hung, S. H., Niksirat, N., Nishikawa, K., \& Campbell, K. L. (2014). Aerobic capacity and upper limb strength are reduced in women diagnosed with breast cancer: A systematic review. Journal of Physiotherapy, 60(4).

Riset Kesehatan Dasar. 2007. Jakarta: Badan penelitian dan pengembangan kesehatan, departemen kesehatan, Republik Indonesia RISKESDAS. 2013. Data Insidensi Kanker Indonesia.

Shahpar, H., Atieh, A., Maryam, A., Fatemeh, H. S., Massoome, N., Mandana, E., Mohammad Esmaeil, A. (2013). Risk factors of lymph edema in breast cancer patients. International Journal of Breast Cancer, 2013, 641818. https://doi.org/10.1155/2013/641818.

SS Mak, YM Lee, SM Tse, FP Ho, E Chan, W Yeo, B Zee (2009) Risk factors for the initiation and aggravation of limfedema after axillary lymph node dissection for breast cancer: Hong Kong Med J 2009;15(Suppl 4): S8-12.

Togawa, K., Ma, H., Sullivan-Halley, J., Neuhouser, M. L., Imayama, I., Baumgartner, K. B.,Bernst ein, L. (2014). Risk factors for self-reported arm lymphedema among female breast cancer survivors: a prospective cohort study. Breast
Cancer Research, 16(4), 414. https://doi.org/10.1186/s13058-014-0414-X

Torre, L. A., Bray, F., Siegel, R. L., Ferlay, J., Lortettieulent, J., \& Jemal, A. (2015). Global cancer statistics, 2012. CA: A Cancer Journal of Clinicians., $\quad 65(2), \quad$ 87-108. https://doi.org/10.3322/caac.21262

Ugur, S., Arıc1, C., Yaprak, M., Mescı, A., Arıcı, G. A., Dolay, K., \& Ozmen, V. (2013). Risk factors of breast cancer-related lymphedema. Lymphatic Research and Biology, 11(2), 7275. https://doi.org/10.1089/1rb.2013.0004

warren, MD et al (2013) The impact df radiation theraphy on the risk of lymphedema after treatment for breast cancer a prospective chohort study. Reveived oct 22, 2013, and in resived form nov 10, 2013. accepted for publication vove 18,2013

Yehia Safwat, Mohammed Shaalan, Mohsen Mokhtar, Mokhtar Hamood (2017), Risk factors of upper-arm lymphedema after breast cancer treatment. J Curr Med Res Pract 2:7378 (C) 2017 Faculty of Medicine, Assiut University 2357-0121

Youlden, D. R., Cramb, S. M., Yip, C. H., \& Baade, P. D. (2014). Incidence and mortality of female breast cancer in the asia-pacific region. Cancer Biology \& Medicine, 11(2), 101-15. https://doi.org/10.7497/j.issn.20953941.2014.02.005

Zhu, Y.-Q., Xie, Y.-H., Liu, F.-H., Guo, Q., Shen, P.P., \& Tian, Y. (2014). Systemic analysis on risk factors for breast cancer related lymphedema. Asian Pacific Journal of Cancer Prevention: APJCP, 15(16), 6535-41. https://doi.org/10.7314/APJCP.2014.15.16.653 $\underline{5}$

Wang Ling, Hui-Ping Li, An-Nuo Liu, De-Bin Wang, Ya-Juan Yang, Yan-Qin Duan, Qing-Na Zhang. A scoring system to predict arm lymphedema risk for individual chinese breast cancer patients. Breast Care 2016;11: 52-56 DOI: $10.1159 / 00044349$ 